\title{
Effect of Orthosiphon stamineus Benth on Hematologic Parameters in Lead Acetat Induced Wistar Rats
}

\author{
DWI RETNONINGRUM ${ }^{1}$, NYOMAN SUCI WIDYASTITI ${ }^{1}$, ARIOSTA $^{1}$ \\ ${ }^{1}$ Department of Clinical Pathology, Faculty of Medicine, Diponegoro University, Semarang, Indonesia \\ Corresponding author: Dwi Retnoningrum, Department of Clinical Pathology, Faculty of Medicine, Diponegoro University, Semarang, \\ Indonesia. Jl. Prof. H. Soedarto, SH., Tembalang-Semarang, Jawa Tengah, Indonesia 50275. Email: dwiretno@fk.undip.ac.id, Telp : \\ $+6285225379937$
}

\begin{abstract}
Introduction: Lead exposure has a negative impact on health. Lead can caused abnormality hematologic parameters. Orthosiphon stamineus Benth is one of the herbal medicines and known to have antioxidant, antiinflammatory, and anti-angiogenesis.

Objective: This study aims to prove the effect of Orthosiphon stamineus Benth on hematologic parameters in lead acetate induced Wistar rat.

Method: The study used posttest only control group design. The samples were 30 male Wistar rats, divided into 5 groups. Normal control group (NC) was given normal saline. Negative control group (NG) was induced by lead acetate $30 \mathrm{mg} / \mathrm{kg} / \mathrm{day}$. GT-50, GT-100, GT-200 was induced by lead acetate and orally administered by 50,100, and $200 \mathrm{mg} / \mathrm{kg}$ Orthosiphon extract once daily for 14 days respectively. One-way Anova and post hoc LSD were used for statistical analysis.

Result: Hemoglobin level and leukocyte count in all group were not different $(p=0.56$ and $p=0.25)$. There was a significant difference in platelet count between all group $(\mathrm{p}=0.035)$. Platelet count in NC group $\left(900 \pm 171 \times 10^{3} / \mu \mathrm{l}\right)$ was significantly higher than NG group $\left(656 \pm 201 \times 10^{3} / \mu \mathrm{l}, \mathrm{p}=0.016\right)$, NG group was significantly lower than $\mathrm{GT}-50$ (869 $\left.\pm 134 \times 10^{3} / \mu \mathrm{l}, \mathrm{p}=0.032\right)$, GT-100 (930 $\left.\pm 162 \times 10^{3} / \mu \mathrm{l}, \mathrm{p}=0.008\right)$ and GT-200 (938 $\left.\pm 148 \times 10^{3} / \mu \mathrm{l}, \mathrm{p}=0.006\right)$

Conclusion: There is a decrement of platelets number in lead acetate exposure. Orthosiphon stamineus Benth may increase platelet counts in lead acetate induced Wistar rat.

Keywords: Orthosiphon stamineus Benth, hemoglobin, leukocytes, platelets
\end{abstract}

\section{INTRODUCTION}

The addition of transportation facilities has a positive impact on human life, but in fact it also has a negative impact including the presence of exhaust gases from vehicles containing lead $(\mathrm{Pb})$. Lead can be harmful to health. Not only from vehicle pollution, lead exposure can also come from the disposal of battery, paint, and textile factory wastes, as well as poor sanitation which can be a contributing factor to lead poisoning in living things. ${ }^{1}$

Lead in the long exposure can accumulate in the body due to its slow elimination process. Ingestion of contaminated food and drinking water is the most common source of lead exposure in humans. Lead will be absorbed through the respiratory or digestive tract. ${ }^{2}$ When absorbed lead will bind with erythrocytes around $30-35 \%$, while $1 \%$ is found in plasma and the other tissues such as liver, kidney, aorta, brain, lungs, and spleen. Symptoms of acute lead intoxication is abdominal colic, whereas at high levels and chronic poisoning will damage the hematological system, nervous system, gastrointestinal and kidney. 1,3 Dobrakowaki et al (2016), found a decrease in hemoglobin levels $(p=0.005)$, an increase in the number of leukocytes $(p=0.031)$, lymphocytes $(p=0.012)$ and platelets $(p=0.036)$ in populations with short-term lead exposure. ${ }^{4}$ Yilmaz et al study (2012) also showed a decrease in hemoglobin $(p=0.018)$ and mean corpuscular volume (MCV) in patients with lead exposure. ${ }^{5}$

Indonesia is a country that has biodiversity, especially plant products, one of which is Orthosiphon stamineus Benth or "kumis kucing" (cat's whiskers) or known as "Java tea" which has been used as herbal medicine for several diseases. ${ }^{6}$ Basheer et al, (2011) mentioned that Orthosiphon stamineus Benth extract act as an anti- inflammatory, antioxidant, antibacterial, and antiangiogenesis. Orthosiphon stamineus Benth leaf extract according to the study contains a number of compounds flavonoids, polyphenols, glycosides, potassium. ${ }^{7}$ The aim of this study is to prove the effect of Orthosiphon stamineus Benth on hematologic parameters in lead acetate induced Wistar rat.

\section{MATHERIALS AND METHODS}

This was an experimental study with randomized, posttest only controls group design. The samples were 25 Wistar rats, with inclusion criteria were aged 6-8 weeks, weight 150-200 grams, healthy condition and no anatomical abnormality. The exclusion criteria of this study were Wistar rats in sick condition (not actively moving). Experimental animals obtained from the Integrated Research and Testing Laboratory, Gadjah Mada University, Yogyakarta, Indonesia.

Samples were divided into 5 groups by simple randomization. Normal control group (NC) was given normal saline. Negative control group (NG) was induced by lead acetate $30 \mathrm{mg} / \mathrm{kg}$ orally once daily. Group GT-50, GT100, GT-200 rats was induced by lead acetate and orally administered by 50, 100, $200 \mathrm{mg} / \mathrm{kg}$ Orthosiphon stamineus Benth leaf extract one daily for 14 days respectively. Each group consisted of 6 Wistar rats.

Orthosiphon stamineus Benth leaves were taken from the buds and collected young stalks, done in an oven at a temperature of more than $40^{\circ} \mathrm{C}$. The extract was made using $70 \%$ ethanol. The graded dose of ethanol extract of Orthosiphon stamineus Benth leaf included 50, 100, and $200 \mathrm{mg} / \mathrm{kg}$ body weight. 
Blood sampling was carried out on day 14 through the retro-orbital vein. Blood was collected in a blood container with EDTA anticoagulants. Hemoglobin level, leukocyte and platelet counts were carried out using hematology analyzer for experimental animals.

One-way Anova and post hoc LSD were employed for analysis of data and mean \pm standard deviation was used for expression of results. The significance level was $p$ $<0.05$. The study protocol had received ethical approval from the Medical Research Ethics Committee of Faculty of Medicine, Diponegoro University and Dr. Kariadi Hospital Semarang, Central Java, Indonesia, with ethical clearance number 019/EC/H/FK-RSDK/IV/2018.

\section{RESULT}

Hemoglobin level, leukocyte and platelet counts with Shapiro Wilk test had normal distribution ( $p>0.05$ ). One Way Anova test was used to determine differences in hemoglobin levels, leukocyte and total platelet counts between study groups. Hemoglobin level and leukocyte counts in all group were not different $(p=0.56$ and $p=0.25)$, but the highest hemoglobin levels $(13.94 \pm 1.2 \mathrm{mg} / \mathrm{dl})$ and leukocyte counts $(9,533 \pm 2,331 / \mu \mathrm{l})$ were in NC group. There was a significant difference in platelet counts between all group $(p=0.035)$. The lowest platelet count was in the NG group. Data distribution of hemoglobin levels, leukocyte and platelet counts were presented in Table 1.

The post hoc LSD test was carried out to find significant differences between groups on the results of platelets counts. Platelet count after the post hoc LSD test showed a significant difference between the number of platelets in the NC and NG group ( $p=0.016)$, while there were no differences between the other groups. Platelet count in NC group $\left(900 \pm 171 \times 10^{3} / \mu \mathrm{l}\right)$ was significantly higher than NG group $\left(656 \pm 201 \times 10^{3} / \mu \mathrm{l}, \mathrm{p}=0.016\right), \quad N G$ group was significantly lower than GT-50 $\left(869 \pm 134 \times 10^{3} / \mu \mathrm{l}\right.$, $\mathrm{p}=0.032)$, GT-100 (930 $\left.\pm 162 \times 10^{3} / \mu \mathrm{l}, \mathrm{p}=0.008\right)$ and $\mathrm{GT}-200$ $\left(938 \pm 148 \times 10^{3} / \mu \mathrm{l}, \mathrm{p}=0.006\right)$.

\section{TABLES}

Table 1. Hemoglobin Levels, Leukocytes and Platelets Counts in All Groups

\begin{tabular}{|c|c|c|c|}
\hline Parameters & Groups & Mean \pm SD & $\mathbf{p}^{*}$ \\
\hline \multirow{4}{*}{$\begin{array}{c}\text { Hemoglobin } \\
\text { (gr/dl) }\end{array}$} & NC & $13.94 \pm 1.23$ & \\
\cline { 2 - 4 } & NG & $13.63 \pm 1.13$ & \\
\cline { 2 - 4 } & GT-50 & $13.75 \pm 1.05$ & 0.56 \\
\cline { 2 - 4 } & GT-100 & $12.84 \pm 1.53$ & \\
\cline { 2 - 4 } & GT-200 & $13.91 \pm 1.49$ & \\
\hline \multirow{4}{*}{$\begin{array}{c}\text { Leukocytes counts } \\
(/ \mu l)\end{array}$} & NC & $9,533 \pm 2,331$ & \\
\cline { 2 - 4 } & NG & $6,650 \pm 2,274$ & \\
\cline { 2 - 4 } & GT-50 & $7,233 \pm 1,344$ & 0.25 \\
\cline { 2 - 4 } & GT-100 & $7,983 \pm 2,092$ & \\
\cline { 2 - 4 } & GT-200 & $7,916 \pm 2,743$ & \\
\hline \multirow{4}{*}{$\begin{array}{c}\text { Platelets counts } \\
\left(\times 10^{3} / \mu l\right)\end{array}$} & NC & $900 \pm 171$ & \\
\cline { 2 - 4 } & NG & $657 \pm 201$ & \\
\cline { 2 - 4 } & GT-50 & $869 \pm 134$ & \\
\cline { 2 - 4 } & GT-100 & $930 \pm 162$ & \\
\cline { 2 - 4 } & GT-200 & $938 \pm 148$ & \\
\hline
\end{tabular}

*One way Annova ${ }^{* *} p<0.05$

Table 2. Comparison of Platelet Count Between Groups

\begin{tabular}{|c|c|c|c|c|c|}
\hline Group & NC & NG & GT-50 & GT-100 & GT-200 \\
\hline NC & - & $p=0.016^{*}$ & $p=0.745$ & $p=0.758$ & $p=0.695$ \\
\hline NG & & - & $p=0.032^{*}$ & $p=0.008^{*}$ & $p=0.006^{*}$ \\
\hline GT-50 & & & - & $p=0.572$ & $p=0.475$ \\
\hline GT-100 & & & & - & $p=0.934$ \\
\hline
\end{tabular}

Post Hoc LSD

\section{DISCUSSION}

In this study the highest mean of hemoglobin level in the normal control (NC) group (13.94 gr/dl), the lowest mean of hemoglobin level in the negative control (NG) group (13.63 $\mathrm{gr} / \mathrm{dl})$. Although the decrease in hemoglobin level was obtained in Wistar rat induced by lead acetate, this reduction was not significant $(p=0.56)$. The anemia results from two basic defects: (1) shortened erythrocyte life span and (2) impairment of heme synthesis. In hemoglobin synthesis, the enzyme $\delta$-aminolevulinic acid synthase $(\delta$ ALAS) catalyzes the synthesis of $\delta$-aminolevulinic acid $(\delta$ ALA), starting with glycine and succinyl CoA. Porphobilinogen is produced from two $\delta$-ALA molecules in the presence of the enzyme $\delta$-aminolevulinic acid dehydratase $(\delta-A L A D)$. Using the enzyme ferrochelatase catalyzes the insertion of Fero ions $(\mathrm{Fe} 2+)$ into protoporfisin IX to form heme. The result of this study was different from previous study. Some in vitro and in vivo animal studies have indicated that lead-induced oxidative damage significantly contributes to enhancement of erythrocytes membrane fragility during lead intoxication. ${ }^{2,8}$

We found the highest mean of leukocytes count in the normal control $(\mathrm{NC})$ group $(9,533 \pm 2,331 / \mu \mathrm{l})$, the lowest mean of leukocytes was found in the negative control (NG) group $(6,650 \pm 2,274 / \mu \mathrm{l})$, whereas in the treatment group by administering Orthosiphon stamineus Benth leaf extract the leukocyte counts increased to approach the normal control group on the Orthosiphon stamineus Benth leaf extract dose of $100 \mathrm{mg} / \mathrm{kg}$ body weight. Although there was a decrease in the number of leukocytes by giving lead acetate exposure but statistically was not significant $(p=$ $0.25)$. This research accordance with Ibrahim et al (2012) and Gani et al (2017), which found the white blood cell decrease but insignificantly change. ${ }^{3,9}$ The decrease of leukocyte counts can caused by accumulation of lead on bone. A study of lead-stable isotope signatures revealed that approximately 40-70 percent of blood lead in adults comes from bone lead. ${ }^{8}$ This was different from previous studies by Dobrakowski et al (2016) which found the results of an increase leukocytes after lead exposure $(p=0.031)$ and AI Waleedi (2016) that total leukocytes counts elevated significantly $(p<0.05)$ in all groups that were administered lead acetate relative to the control. ${ }^{10,11}$

The highest mean of platelet in the GT-200 group with $200 \mathrm{mg} / \mathrm{kg}$ Orthosiphon stamineus Benth leaf extract (938 $\left.\pm 148 \times 10^{3} / \mu \mathrm{l}\right)$, the lowest mean of platelet count was in the NG group $\left(657 \pm 201 \times 10^{3} / \mu \mathrm{l}\right)$, while in the mean of normal control group was $900 \pm 171 \times 10^{3} / \mu \mathrm{l}$. In the treatment group with the administration of Orthosiphon stamineus Benth leaf extract showed that platelet count was higher in accordance with the dose. The difference in platelet counts between the treatment groups obtained significantly different results $(p=0.035)$. This result was different from the study of Dobrakowski et al, platelets have important role in inflammatory conditions, in lead intoxication platelet counts will increase due to pro-inflammatory cytokines and oxidative stress conditions, so there will be endothelial injury, decreased nitric oxide levels (NO), tissue plasminogen activator and enhancement of plasminogen activator inhibitor-1. $10 \mathrm{Al}$ Naimi et al, said that administration of lead acetate at $75 \mathrm{mg} / \mathrm{kg}$ body weight at 
20 and 40 days cause moderate hyperplasia of hematopoietic tissue with proliferation of megakaryocytes. ${ }^{12}$ We found significant difference between the number of platelets in NC and NG group ( $p=0.032)$. This showed that lead exposure in this study reduced platelet count and administration of Orthosiphon stamineus Benth leaf extract in Wistar rat induced by lead will increase platelet count. Free radicals such as reactive oxygen species (ROS), including hydroxyl radicals, superoxide anions, and hydrogen peroxide, play an important role in increasing the destruction of tissues. The antioxidant activity of phenolic compounds is found mainly because it inhibits its redox through neutralization and free radical cooling. 6,13

\section{CONCLUSIONS}

In present study, we reported platelet count will decrease in lead acetate exposure and an increase platelet counts by giving multilevel Orthosiphon stamineus Benth leaf extract.

Acknowledgments: This study was financially supported by Research Grant Number 46/UN7.5.4/HK/2018, from Faculty of Medicine, Diponegoro University, Semarang, Central Java, Indonesia.

\section{REFERENCES}

1. Carocci A, Catalano A, Lauria G, Sinicropi M, Genchi G. Lead Toxicity, Antioxidant Defence and Environment. Rev Environ Contam Toxicol. 2016;238(November):2013-2016.

2. Sharma B, Singh S, Siddiqi NJ. Biomedical implications of heavy metals induced imbalances in redox systems. Biomed Res Int. 2014.

3. Ibrahim NM, Eweis EA, El-Beltagi HS, Abdel-Mobdy YE. Effect of lead acetate toxicity on experimental male albino rat. Asian Pac J Trop Biomed. 2012;2(1):41-46.

4. Dobrakowski M, Pawlas N, Hudziec E, et al. Glutathione, glutathione-related enzymes, and oxidative stress in individuals with subacute occupational exposure to lead. Environ Toxicol Pharmacol. 2016;45:235-240.

5. Yilmaz H, Keten A, Karacaoglu E, Tutkun E, Akçan R. Analysis of the hematological and biochemical parameters related to lead intoxication. J Forensic Leg Med. 2012;19(8):452-454

6. Silalahi M. Orthosiphon stamineus Benth (Uses and Bioactivities). Indones J Sci Educ. 2019;3(1):26.

7. Basheer MKAM, Majid AMSAA. Medicinal Potentials Of Orthosiphon stamineus Benth. Webmed Cent. 2011;1(12):17.

8. Patrick L. Lead toxicity, a review of the literature. Part I: Exposure, evaluation, and treatment. Altern Med Rev. 2006;11(1):2-22.

9. Gani MU, Siddiqui MSI, Islam K, Ahmed S, Mostofa M. Study on hematological alterations in experimental lead toxicosis in long evans rats. Malaysian $J$ Vet Res. 2017;8(1):11-18.

10. Dobrakowski M, Boroń M, Czuba ZP, et al. Blood morphology and the levels of selected cytokines related to hematopoiesis in occupational short-term exposure to lead. Toxicol Appl Pharmacol. 2016;305:111-117.

11. Alwaleedi SA. Hematobiochemical changes induced by lead intoxication in male and female albinomice. Natl J Physiol Pharm Pharmacol. 2016;6(1):46-51.

12. Naimi RAA-, Zahroon OS, Taae EHA-. Toxicopathological Study of Lead Acetate Poisoning in Growing Rats and the Protective Effect of Cysteine or Calcium. Al-Anbar J Vet Sci,. 2011;4:26-39.

13. Han Jin C, Hussin A. Effect of the Orthosiphon Stamineus, Benth on Aminopyrine Metabolism in Rat Hepatocytes. Malaysian J Pharm Sci. 2007;5(1):25-32. 